\title{
Clinical Legal Education in the Law University: Goals and Challenges
}

\author{
Margaret Barry 1
}

\section{Introduction}

Calls for reform of legal education in India have focused on preparation and relevance. The route to achieving both has consistently been linked to clinical legal education. In 1999, I heard one of the leaders of legal education in India, Dr. Madhava Menon, discuss his goals for clinical legal education in at the first Global Alliance for Justice Education Conference in Trivandrum. ${ }^{2}$ I learned at the time that he had been invited to lead a new law school in the country, and he made it clear that clinical legal education would be central to the new law school model that he intended to pursue, a model based on recommendations that grew out of prior assessments of legal education in India. ${ }^{3}$ Under this model, law students would be trained to be productive members of a community of lawyers that had refined the skills needed to develop and implement creative

1 Associate Professor of Law, Columbus School of Law, The Catholic University of America. Professor Barry visited NALSAR Law University as a Fulbright Senior Specialist in August 2005. I thank Frank S. Bloch (Professor of Law, Vanderbilt University) and Clark D. Cunningham (W. Lee Burge Professor of Law \& Ethics, Georgia State University School of Law) for their thoughtful input. I am particularly grateful to Amita Dhanda (Professor, NALSAR Law University) for encouraging me to write the article and for her feedback.

2 "GAJE is a GLOBAL ALLIANCE of persons committed to achieving JUSTICE through legal EDUCATION. Clinical education of law students is a key component of justice education, but this organization also works to advance other forms of socially relevant legal education, which includes education of practicing lawyers, judges, nongovernmental organizations and the lay public." GAJE Introductory Statement, http://www.gaje.org/ (last visited Dec.31, 2007). It held its first conference in 1999 in Trivandrum, State of Kerala, India.

3 "The Bar Council of India gave a fresh look at legal education at an All India Seminar held at Bombay in $1977 \ldots$. On the basis of the recommendations of this Seminar, a dialogue with the universities teaching law was initiated by the Council which eventually, in 1982, resulted in a new 5-year integrated professional programme after $10+2$ school education. Two important features of the new pattern of legal education which was to come into force from the year 1987-88 are the introduction of a two-year Pre-law Study consisting of several social science courses, and a six-month intensive compulsory clinical education." N.R. MADHAVA MENON, CLINICAL LEGAL EDUCATION, Chapter 1, Clinical Legal Education: Concept and Concerns, 20 (1998). Dr. Menon describes The National Law School of India (NLSIU) as the first school developed under this model. See id. at Chapter 15, Development of Clinical Teaching at the National Law School of India: An Experiment in Imparting Value Oriented Skills Training, 238-263. The importance of clinical legal education has been touted by the Bar Council of India and various law commissions for decades. Id.; Krishnan, infra note 18; Bloch \& Prasad, infra note 5, at 172 (discussing in Part II inclusion of clinical legal education in efforts to reform legal education). 
strategies for addressing the pressing demand for social justice in the country. ${ }^{4}$ The approach reflected a connection between responsibility for the underserved and goals for clinical legal education in India that dates back to collaboration with academics from the United States in the late 1960 's. ${ }^{5}$

A series of high-level committees have made it progressively clear that this connection is central both to improving the quality of legal education in India and to making it relevant to the most pressing problems facing the society. ${ }^{6}$ In 1973, the Expert Committee on Legal Aid of the Ministry of Law and Justice recommended introducing clinical legal education with a focus on poverty issues into law schools. ${ }^{7}$ In 1977, the Committee on National Juridicare distinguished the legal services approach in the United States that had influenced the earlier recommendations, pointing out that law schools should establish legal aid clinics that prepared students to help achieve the structural changes India needed to distribute the material resources of the country more effectively. This was followed in 1981 by the Committee for Implementing Legal Aid Schemes' call for establishment of legal aid clinics as part of its recommendations. ${ }^{8}$

Despite these high-level endorsements, progress towards establishing clinical programs in Indian law schools has been modest. 9 Several barriers account for this result. Academics, the legal community and the Bar Council never seriously embraced the establishment of clinical programs. ${ }^{10}$ Furthermore, the desire to pursue opportunities in the global market made it difficult to keep the focus on legal strategies that would protect the rights and immediate needs of the poor. ${ }^{11}$ Many Indian law students and their families, like their counterparts in the United States, want legal careers that are lucrative, and these goals have not been sufficiently connected to the benefits of implementing clinical programs and teaching methods, in either country. ${ }^{12}$

4 Professor Krishnan identifies Madhava Menon not as the creative force for the new law school model so much as the person with the vision and drive to bring it into being. He described Dr. Menon as drawing on a range of influences, including the 1964 Gajendragadkar Committee Report and the work of then Dehli law professor Upendra Baxi, who went on to be one of the most prominent legal scholars in India and who currently is on the faculty of the University of Warwick (UK). Krishnan, infra note 18 , at $480-484$.

5 Frank S. Bloch \& M.R.K. Prasad, Institutionalizing A Social Justice Mission for Clinical Legal Education: Cross-National Currents from India and the United States, 13 Clinical L. Rev. 165, 168 (2006) (discussing the influence of educational exchanges funded by the Ford Foundation in the late 1960's and early 1970's and the opportunities they provided for American and Indian law teachers to shared developments in the law-and-poverty curriculum, including the emerging clinical methodology.).

6 Id at $173-175$.

7 Id at 174 (The Committee "observed that students' encounters with the problems of poverty and exploitation would change their outlook when they became lawyers, and as a result they would not treat clients simply as facts but as living neighbors.")
8 Id at 175.

9 Id (discussing the limited response by a few of the law schools).

$10 \mathrm{Id}$ at $176-78$ (listing the lack of practical knowledge and the lack of financial assistance to law schools to meet the expenses of running clinical programs, lack of incentives for faculty such as reduced teaching loads, the fact that the Advocates Act prohibits full-time law teachers from practicing law, the lack of licensing provisions for law students, and the general sense that legal education in India has been neither meaningful or relevant as the reasons why clinical legal education has not taken root). See also, Krishnan infra note 18 .

11 For an interesting discussion on the dynamics of the global market, including India's role, see THOMAS L. FRIEDMAN, THE WORLD IS FLAT: A BRIEF HISTORY OF THE TWENTYFIRST CENTURY (2005).

12 Clinics in the United States broach this issue implicitly or explicitly by discussing the importance of the skills learned through clinical courses in developing professional competence. It would be interesting to learn the extent to which such discussions explore the possibilities for pursuing social justice goals in a range of practice settings. As I reflect on such discussions in my teaching, I am 
The failure of the committee recommendations to yield significant change led to several initiatives. In 1988 and 2000, two successive Curriculum Development Committees sought to improve the overall quality of legal education and make law school curricula more responsive to the pressing needs of India's poor. Neither had much impact. However, in 1994 the Ahmadi Committee Report included in its recommendations the establishment of premier law schools to improve legal education. The report referenced the new National Law School of India University in Bangalore, which at the time was run by Dr. Menon, and recommended in the establishment of the new law universities based on that model.13

Another significant step was taken in 1997 when the Bar Council of India directed all law schools to incorporate four Practical Papers into their curricula. Paper I requires instruction in litigation skills; Paper II requires instruction in drafting skills; Paper III requires instruction in ethical and bar-bench relations; and Paper IV requires public interest lawyering. It was followed in 2002 by the Law Commission of India's report stating that clinical legal education should be compulsory. 14 Response to these requirements has been modest at best. The reason can be seen in the explanation for why previous efforts at instituting new standards failed: means were not part of the package. 15 However, developing a vision for the possibilities of clinical legal education within existing constraints has been the focus of trainings offered in 2007 across the sub-continent. ${ }^{16}$

In light of the possibilities suggested by these trainings, this article considers how the history of high-level assessment, recommendation, and demand might be pursued in the new, elite law universities. Should developing the analytical and practical competencies needed for addressing India's critical issues of poverty and access to justice indeed be a priority for the law universities? If so, how should it be achieved? My perspective is based, inevitably, on my clinical legal education experience in the United States and, to a lesser extent, on my exposure to NALSAR Law University (hereinafter "NALSAR"), which I refer to as an example of a law university response to the intended reform measures. I begin by discussing clinical legal education and why it is a critical aspect of a lawyer's professional training. I draw on assessments made of U.S. law schools that are similar to those that the various committees and commissions have made in India. The assessments conclude that law schools should more effectively connect the substantive education they provide to professional practice, and that this connection should include a firm understanding of and commitment to responding effectively to the needs of underserved members of the community. While the approach in India is driven by the particular needs that affect such a rich, diverse, and challenging country, the premise is the same: the preparation of law professionals must effectively be connected to the social justice imperatives of their communities. As Paulo Freire has

aware that they have not been as focused and in depth as they could be. One approach might be to invite corporate counsel and partners from major law firms to explore with my clinic students the opportunities for identifying and pursuing the common good that they see or are open to in the context of their practices.

13 Bloch \& Prasad, supra note 5, at 178-79.

14 Law Commission of India, 184th Report (2002) at 95.

15 Block \& Prasad, supra note 5 at 180.
16 Five regional trainings were offered in 2007 through the South Asian Forum of Clinical Law Teachers (SAFCLT) and the Menon Institute of Legal Advocacy Training (MILAT). MILAT is the twoyear old institute chaired by N.R. Madhava Menon that is devoted to human rights promotion, law and judicial reforms and professional development programs. The goal of the trainings has been to "train about 250 clinical law teachers in the country capable of effectively teaching at least the four practical training papers described by the [Bar Council of India]." MILAT announcement, dated November 23, 2007, copy on file with the author. 
said, "We make the road by walking." 17 This article is intended to explore steps towards implementing the goals for legal education that have been expressed over the years and that could yield significant contributions to India's future.

\section{Why Clinical Legal Education in India?}

Clinics expose students to the impact that the practice of law has on people. No one should pretend that they are prepared to practice without a sense of this impact and a constructive way to think about it. This perspective has significant implications for the way legal education is approached in India. It is law schools that must foster a contextual understanding of what lawyers should do to meet the needs of the country. This means connecting students with communities and involving them in creative solutions that focus on the common good.

The new model for law schools - the law university - grew out of a perceived need to enhance the quality of legal education in India. The universities represent a bold move to reinvent legal education practices. The practices that were found lacking in law schools were overcrowded classrooms, lack of rigor in teaching, lack of attention to socio-economic problems, and a general lack of preparation for professional practice. 18

As with other law schools in India, students come to the national law universities straight out of $10+2.19$ Arguably, these students are too young and their education too narrow to take full advantage of professional training. ${ }^{20}$ In the United States, law is a post-graduate study; university

17 MYLES HORTON \& PAULO FREIRE, WE MAKE THE ROAD BY WALKING: CONVERSATIONS ON EDUCATION AND SOCIAL CHANGE (1990).

18 See Jayanth K. Krishnan, Professor Kingsfield Goes to Delhi: American Academics, the Ford Foundation, and the Development of Legal Education in India, $46 \mathrm{Am}$. J. Legal Hist. 447 (2004). Professor Krishnan discusses the multiple assessments of Indian legal education by the Indian government and by American scholars sent by the Ford Foundation. The article chronicles the observations and frustration that the various Ford scholars conveyed, most generally emphasizing the importance of Indian leadership in developing a meaningful solution for societal needs and the legal education reforms designed to address them. In truth, Professor Krishnan's article served to emphasize my own hesitance in plunging forward with suggestions for implementing the clinical legal education aspects that seemed to be so central to the national law school model. Clinical legal education in the United States is a work in progress. The connection to educational goals is not as explicit or as developed as it should be by now. Indeed, India has been more explicit in stating the importance of clinical legal education. Still, India has not taken the steps towards clinical legal education that its institutional objectives would suggest. The door is open, but the path relatively untraveled. In part, this is due to systemic barriers discussed below, but it is also due to the ongoing need to identify the relevance of various possible clinical offerings to the range of professional obligations Indian lawyers will need to meet. As Upendra Baxi points out, Indian lawyers need to focus on the social relevance of law and understand their professional obligation to serve their community meaningfully. Id at 483. I also heard Professor Baxi make a similar point at a lecture at NALSAR on August 15, 2005. As many of my law students at NALSAR pointed out, they need to understand how socially relevant practice will translate into a profession in which they can earn a decent living. Opportunities previously unheard of within India's borders have become available through globalization. Id at 494. The law university has both the challenge and the obligation to help students integrate and prepare to respond to these challenging demands. See also Bloch \& Prasad, supra note 5, at 167-172 (discussing in Part I a brief overview of the social justice mission in clinical legal education in India).

19 These students are equivalent in age to American high school graduates.

20 The following curriculum for the first two years developed for the National Law University at Bangalore indicates how social science classes are integrated: "First Trimester - Sociology I, Economics I, Legal Methods Materials \& Processes, Torts I, English and Legal Language; Second Trimester - Economics II, Political Science I; History I, Contracts I, English \& Legal Language 
graduates enter law schools to obtain a doctorate in law. However, many other countries follow a pattern similar to India's, for economic if no other reasons. ${ }^{21}$ The expense of attending college prior to preparing for professional practice can be prohibitive, particularly when undergraduate study is imposed as a condition precedent. The universities offer a five-year program, the first two years of which include social science and economics courses along with law courses. Economics and an expansive view of access to education have led to overcrowding in the professional institutions. The number of students attending law schools in India does not necessarily represent vocation or an expectation of entering the profession; students also enter law school as a matter of opportunity or indecision.22 The national law universities narrowed this pool by raising admissions standards and charging students to attend, setting aside scholarships to assure access to some of the qualified students who could not otherwise matriculate.

Reflecting some attention to the Bar Council's Practical Paper requirements, ${ }^{23}$ students are required at NALSAR Law University to spend time in practice settings in four of their five years. ${ }^{24}$ The placements have the potential to allow students to interact with the legal community and experience the law in context. However, the placements are apparently student-run projects rather than the product of faculty supervision and educational rigor. ${ }^{25}$ Students organize the placements,

(Continued); Third Trimester - Sociology II, Contracts II, Constitutional Law I, Torts II, English and Legal Language (Continued); Fourth Trimester - History II, Political Science II, Constitutional Law II, Family Law I; Fifth Trimester - Jurisprudence I, Constitutional Law III, Criminal Law I, Family Law II; Sixth Trimester - Criminal Law II, Administrative Law, Property Law, Political Science III." Krishnan, supra note 18, at Appendix, 498-499. Several of the students I taught at NALSAR expressed the concern that they had an insufficient foundation for their professional degree and felt that they could not prepare to be effective in the profession with such a narrow educational base. However, this seemed to express a sense that they were missing something that American students had the benefit of more than a specific lack of foundation for their professional training.

21 See, e.g., Frans J. Vanistendael, Quality Control of Students and Barriers to Access in West-European Legal Education, 43 S. Tex. L. Rev. 691, 692 (2002) ("With the exception of the U.K. and Ireland, conditions for admission to law schools are totally different from those in the United States. First, there is no buffer of college between high school and the start of law school."); Philip F. Iya, The Legal System and Legal Education in Southern Africa: Past Influences and Current Challenges, 51 J. Legal Educ. 355, 360 (2001).

22 Even at NALSAR Law University, a number of law students expressed a detachment with regard to their professional futures that I found surprising. I have encountered a similar perspective while teaching and talking with students at the University of Montenegro School of Law. Many of the students there are not sure that law is a career they want much less have any hope of effectively pursuing.

23 The Bar Council has required all Indian law schools to include the four Practical Papers in their curricula since 1998. Bloch \& Prasad, supra note 5, at 181, and at 209 (describing the details of the syllabus and mode of evaluation for the four Practical Papers, or core courses, to be implemented in the law universities). .

24 This is consistent with the model instituted by Dr. Menon. Referring to establishment of the first law university, the National Law School at Bangalore, Professor Krishnan noted, "Menon institutionalized into the curriculum a mandatory two-month internship that students would need to complete every year during their holiday period. Krishnan, supra note 18 at 489.

25 I worked with 57 students who are in their fifth year at NALSAR. Each of them had externship placements over the years. The placements were organized by the students. A few had extraordinary placements. One had traveled to the Hague to intern at the World Court, and was thrilled by the opportunity he had to do legal research and writing on interesting cases. Another student had interned for an attorney who had worked on interesting cases and included her in the case preparation. The vast majority of students said that their placements were disappointing. They described being placed at desks but given no work or opportunity to observe work, being given tasks completely unrelated to legal practice and having supervisors who had no idea what was expected or what to do with them. One student said, "I got to the office and the judge asked me what I thought I should do. I said I was not sure. He did not 
interact with the relevant offices and appear for work. The school is not involved in this exchange in any meaningful way other than to register the fact that each placement occurred.

Beyond these placements, experiential learning is limited at NALSAR to moot court and a few classroom simulations. ${ }^{26}$ How did clinical legal education remain largely undeveloped in this new institution given the goals that supported development of the law universities?27 In part, the necessary emphasis placed on building physical facilities and attracting highly qualified faculties and students provides insight. Establishing new institutions in which traditional teachers organize the curriculum and teach the courses is not a prescription for significant curricular change, even though the framework of fewer students and greater resources suggest some opportunity for improvement. Lack of experience in clinical teaching, the demand on teaching resources that clinics make and the Bar Council's failure to provide institutional support for the clinical legal education espoused contribute to the difficulty realizing desired change. Indeed, the Bar Council sends the message that law teachers are to be disengaged from the practice of law by denying the license to practice it. 28 Thus, the substantive curricular changes articulated by Dr. Menon and urged in the many reports appear to be eluding the new institutions, ${ }^{29}$ though, paradoxically, there

seem to know what I should do either, so I hung around and did not do much." Several others had similar examples. Having students responsible for their externship placements can be empowering and can yield a wide range of opportunities that reflect student interests, but this does not mean that the school should view its role in the process as passive. The placements are an educational requirement, and the school has an interest in assuring that the experiences students have are valuable.

26 When I taught at NALSAR Law University in 2004, the simulation that I spent nine days teaching was part of a clinic course, one that had been evolving that year and that did not appear to be an established part of the curriculum. Prior to my arrival, the students in this course had done a mock criminal trial, but the readings for the course and other preparation for that simulation were not apparent. As far as I could tell, apart from this simulation course, moot court and the placements discussed in the text that follows, there were no other skills or clinical course being taught at the school.

27 Even at the National Law University at Bangalore the model for institutional reform, see supra note 29, clinical opportunities seem limited to observing court or lok adalat proceedings. It has been hard to get a handle on what is happening at the many law programs in India outside of the law universities. V. M. Salgaocar College of Law, infra note 30 , is one example of what is happening. According to Subhram Rajkhowa of Gauhati University, Assam, India, "the law clinics may be categorized under three heads, those under the National Law schools, those under the central universities and those under the state universities, the third category being the least structured." Subrhram Rajkhowa, Globalizing Clinical Education to Protect the World's Health
Environment, University of Maryland School of Law, April 11-13, 2007, http://www.law.umaryland .edu/specialty/environment/WardKershaw07/rajkh owa.pdf (last visited Dec. 31, 2007).

28 For example, in India, law faculty are not allowed to hold a license to practice law. See, Bar Council of India Rules, Part VI, Chapter 2, Section VII Restriction on Other Employments. ("An advocate shall not be a full-time salaried employee of any person, government, firm, corporation or concern, so long as he continues to practise, and shall, on taking up any such employment, intimate the fact to the Bar Council on whose roll his name appears and shall thereupon cease to practise as an advocate so long as he continues in such employment.") The reason for such limitation may be to assure that law faculty are focused on teaching instead of suborning their teaching obligations to the demands of legal practice. A similar concern is reflected in the accreditation standards for American law schools. Section of Legal Education and Admissions to the Bar, American Bar Association, Standards for Approval of Law Schools (2006-7) [hereinafter ABA Standards], Standard 402(b) provides that a full-time faculty member's primary professional employment must be with the law school and anything outside must not "unduly interfere" with law school responsibilities.

29 Dr. Menon views clinical experiences as a central element of legal education, promoting social and professional responsibilities within the legal practice - surpassing the mere academic exercises of legal education. Menon, supra note 3, at 4-6. Clinical education is to encompass active participation by the students, under the careful supervision of the faculty, to learn about the practical applications of legal skills and processes in the context of the political, social and economic 
is some evidence of progress towards the articulated goals in other law schools. ${ }^{30}$ Since interest in clinical legal education in India was nourished by developments in the United States, ${ }^{31}$ to what extent is what has been happening in the United States instructive?

\section{Legal Education Reform in the United States}

Legal education in the United States has been repeatedly criticized for its failure to adequately prepare students for the practice of law. ${ }^{32}$ The critique has come in the form of high-level reports, ${ }^{33}$ judicial commentary ${ }^{34}$ and numerous law review articles that call for more relevant training. 35

conditions of their country and society. Id. at 10-11. Referring to the first of the national law universities, the National Law School at Bangalore, Professor Krishnan concluded, "Menon had realized his dream - to construct an Indian law school that would emphasize pedagogy, analytical rigor, clinical training, and public service." Krishnan, supra note 18 , at 493. However, it does not appear that even Bangalore has realized the dream with regard to clinical training.

30 V. M. Salgaocar College of Law Legal Aid Society, which began in 1998, is an example of what can be achieved in India, and is an example of India's potential as a leader the international clinical legal education movement. It operates thirty-five permanent free legal aid cells throughout the state of Goa. Each cell consists of a team of two students. The cells are set up and housed in government buildings, schools, and church or temple premises. Students carry out awareness campaigns, provide legal advice and pursue remedies such as meeting with the other party, meeting with government officials and providing legal referral services. The students also perform paralegal aid services, such as visiting jails, registering marriages, births, and deaths, obtaining ration cards, and preparing affidavits. They also prepare and file documents that are required for obtaining benefits under various welfare schemes. Students also work with faculty members to petition relevant authorities who are obliged under law to remedy the injustice. If relief is not provided, the students work with lawyers to file a petition before the High Court. Students can argue these cases under special rules that allow any member of the public to present such cases. Bloch \& Prasad, supra note 5 at 203-206. The authors also presented a workshop at the GAJE Conference in Cordoba, Argentina in 2006, using examples of two activities Legal Aid Society students and exploring with participants the value including critical assessment of the of the work undertaken by clinical law students and their teachers. Report of the 4th GAJE Conference, at 20, http://www.gaje.org/ (last visited Dec. 31, 2007).

31 See Krishnan, supra note 18.
32 This is an issue that law schools in the United States have either struggled with or ignored. In the Third Wave article, my co-authors and I discuss experiments and programs at law schools that have sought to address the need for a broader impact within their curricula. See Barry et al., infra note 58, at 32-50. We quote former Dean John Sexton of New York University as saying that "we must abandon the "coverage" paradigm - that is, we must abandon the notion that there is a certain, fixed body of doctrine which must be covered, and instead use substantive courses as a platform for teaching the range of skills that students should learn." Id. at 49-50. See also, Russell Engler, The MacCrate Report Turns 10: Assessing Its Impact and Identifying Gaps We Should Seek to Narrow, 8 Clinical L. Rev. 109 (2001); ROY STUCKEY ET AL., BEST PRACTICES FOR LEGAL EDUCATION: A VISION AND A ROAD MAP (2007) [hereinafter BEST PRACTICES] (For the past several years, the Clinical Legal Education Association has sponsored a project to analyze legal education and develop a comprehensive guide for achieving the optimum approach to teaching law. The result is BEST PRACTICES. The publication is a useful resource for any law school committed to evaluation of its approach to legal education.).

33 See Stuckey, supra, at 11-37; Robert MacCrate, Legal Education and Professional Development - An Educational Continuum, 1992 A.B.A. Sec. Legal Educ. \& Admissions to Bar 213 [hereinafter MacCrate Report]; WILLIAM M. SULLIVAN, ANNE COLBY, JUDITH WELCH WEGNER, LLOYD BOND, \& LEE S. SHULMAN, EDUCATING LAWYERS : PREPARATION FOR THE PROFESSION OF LAW (2007) [hereinafter EDUCATING LAWYERS].

34 See Warren E. Burger, The Special Skills of Advocacy: Are Specialized Training and Certification of Advocates Essential to Our System of Justice?, 42 Fordham L. Rev. 227 (1973); Harry T. Edwards, The Growing Disjunction Between Legal Education and the Legal Profession, 91 Mich. L. Rev. 34 (1992)

35 See, e.g., EDUCATING LAWYERS, supra note 38; BEST PRACTICES, supra note 32; Alan Watson, Legal Education Reform: Modest Suggestions, $51 \mathrm{~J}$. 
When Professor Langdell championed the casebook method and the use of Socratic dialogue in the early 1900's, his goal was to establish legal education as an academic discipline. ${ }^{36}$ That concern still casts a shadow that arguably dissociates legal education from significant aspects of its obligation to develop professional competency. 37 This is not to say that Langdell's method, particularly as it has evolved to include problem solving and critical studies, is not important or relevant. It is recognize that more is needed. The concern that too much is asked of law schools if they are expected to expose students to the law both in theory and practice must not be the end of the analysis. Theory and practice are intertwined in law, as they should be in any profession. This connection is not fully acknowledged by law schools, and the educational programs have suffered as a result.

The Carnegie Foundation report, EDUCATING LAWYERS: PREPARATION FOR THE PROFESSION OF LAW (2007), underscores the need for change in the approach to legal education. ${ }^{38}$ The report cites the newly published BEST PRACTICES FOR LEGAL EDUCATION: A VISION AND A ROADMAP, a project of the Clinical Legal Education Association that takes an in depth look at all aspects of legal education in the United States and recommends methods for improvement. ${ }^{39}$ Both books discuss the importance of clinical programs and the use of clinical methodology across the curriculum to achieve the necessary integration of substantive law and professional skills and values. 40 All accredited law school in the United States have clinical programs. Given the growth of clinical programs in law schools in the United States, one might wonder why the statements continue to be made that link their importance to needed improvement. A fundamental problem with the approach to clinical programs, and this is also true of "skills" courses in most U.S. law schools, is that they are viewed as nonessential and/or unrelated to the substantive law courses offered. ${ }^{41}$ The hard work of integrating experiential

Legal Educ. 91 (2001); Carrie Menkel-Meadow, Taking Problem-Solving Pedagogy Seriously: A Response to the Attorney General, 49 J. Legal Educ. 14 (1999).

36 Barry et al., infra note 58, at 5-6.

37 One skill is valued: legal analysis. One task is in direct conflict with achieving more: coverage of substantive law. The idea that the skills and values addressed in clinical courses are important aspects of legal education is seen as beyond the scope of what can reasonably be achieved in a substantive law course.. This is true despite the weight of criticism referenced above. This is true because, while the bench and bar claim they want change, hiring is based on performance in the very courses that teach the skill emphasized by law schools. Furthermore, entry into the profession is determined by who passes bar examinations, and these examinations essentially ignore professional values and skills other than legal analysis. In sum, the training law schools provide has been roundly criticized, but there is insufficient incentive to change.

38 In their preliminary summary, the authors of EDUCATING LAWYERS make seven specific recommendations: that law schools (1) offer an integrated curriculum; (2) join lawyering, professionalism and legal analysis from the start; (3) make better use of the second and third years of law school; (4) support faculty teaching across the curriculum; (5) design the program so that students and faculty weave together disparate kinds of knowledge and skill; (6) recognize a common purpose in achieving professionalism; and (7) emphasize interdisciplinary learning The report itself emphasizes the need to integrate practical and theoretical learning. See generally EDUCATING LAWYERS, supra note 38.

39 See BEST PRACTICES, supra note 32.

40 BEST PRACTICES also emphasizes the importance of outcome assessment as a means of determining the extent to which approaches to achieving quality legal education are effective. It argues that legal education is unique in its failure to reflect on the effect of its teaching choices. BEST PRACTICES, supra note 32 , at 42 . It notes that legal educators in Great Britain have begun to explore outcome assessment methods. Id. at 45-46.

41 The emphasis is on teaching a set of required first year courses and other courses that appear on state bar examinations, have traditionally been offered, are favored by members of the faculty, or cover emerging areas of law. The approach is driven by history and evolution, but not necessarily reflection on what is needed to produce thoughtful and 
education into the curricula has not happened in this profession, raising serious concerns about the quality of professional preparation.

What do clinical courses offer that these analyses and critiques of legal education find so important? First of all, the emphasis on clinical programs addressing skills and values that substantive law classes do not reach may suggest that clinical programs fully prepare students to enter the profession as competent practitioners. No such argument is intended. Clinical programs do well if they introduce students to the competencies they will need, strategies for building expertise and critical assessment of the lawyer's role. While the traditional American classroom uses casebooks and the Socratic method to expose students to a body of substantive material and develop their ability to analyze the material, 42 the range of competencies that a clinical course seeks to develop is broader. They include interviewing, fact investigation, an extensive application of problem solving skills, attorney-client relations, negotiation and other alternative dispute resolution methods, ethical considerations, pre-trial and trial skills. They are taught using methods that include role-playing, simulations, brainstorming, highly interactive discussions, regular indepth feedback, and direct client representation. ${ }^{43}$ Significantly, they instruct by helping students to build on their experiences.

Second, clinical courses expose students to opportunities to use legal expertise to address issues of social concern, particularly the needs of the poor. Regardless of whether students intend to work in public interest law, they need to be aware of their obligations to contribute to their communities and of the special role they are becoming equipped to play in addressing a range of social problems. While the classroom can raise theoretical issues about social justice, access to legal interventions and reform, understanding the problems in terms of access, application, and sufficiency comes from well-supervised work with poor people. Thus, these issues are best raised through direct service to disadvantaged clients, either through representation or some other opportunity to work closely with them in order to understand the problems and the attorney's special ability to provide effective assistance.

Clinical programs in law schools across the United States have addressed one or both of these goals through experiences that are discussed below. The discussion considers these approaches in relation to what might make sense for the law universities, not as a prescription for what should be the ultimate or ideal approach but rather as a way to begin to think about moving along the path to implementing some of the reforms that have been advocated for so long.

effective professionals. There is a significant trend away from teaching law courses as though they exist in a theoretical vacuum, unrelated to other substantive law, legal practice and the complexities of the society in which it all finds relevance. However, the priority remains legal analysis and coverage. See, Janet Weinstein \& Linda Morton, Interdisciplinary Problem Solving Courses as a Context for Nurturing Intrinsic Values, 13 Clinical L. Rev. 839, 847 (2007); Thomas F. Geraghty, Legal Clinics and the Better Trained Lawyer (Redux): A History of Clinical Education at Northwestern, 100 Nw. U. L. Rev. 231 (2006); Roy Stuckey, Teaching with Purpose: Defining and Achieving Desired Outcomes in Clinical Law Courses, 13 Clinical L. Rev. 807 (2007).
42 Many law teachers are moving away from the Socratic method and/or integrating more problemsolving approaches in their teaching. See e.g. Robert J. Rhee, The Socratic Method and the Mathematical Heuristic of George Polya, 81 St. John's L. Rev. 881 (2007) (bemoaning the decline in popularity of the Socratic method of teaching and suggesting that it would be more attractive if combined with mathematician George Pólya's approach to problem-solving).

43 See BEST PRACTICES, supra note 32 at 165-167. 


\section{Contemplating the Path}

The strong support for clinical legal education in India has resulted in an assumption of its benefits, but it is not clear that law universities have considered how it relates to educational priorities. Thus, a necessary step is to assess what aspects of clinical legal education are important and why. Insight can be gained from looking at the committee and commission reports, but how should their calls for socially relevant learning experiences and to use students to address India's mandate to provide legal aid be approached by the universities? ${ }^{44}$

To avoid critiques leveled against American law schools, one important goal would be to figure out how to integrate values and appropriate skills into the substantive law classes. Given India's commitment to access to legal aid and the percentage of the population living in poverty, social science courses that are currently included in the law university curricula provide an excellent opportunity to help students consider innovative interventions and collaborations through which lawyers can make useful contributions.

There is a special danger of sacrificing educational objectives in order to respond in some way to the huge demand for legal services. The idea that law universities should attempt to bridge the chasm between the promise of legal aid to the poor in India and the reality of access is in direct conflict with the educational mission. The goal of the law universities should be to create the space for analysis and creative problem solving, and this cannot effectively happen where the competing goal is coverage of huge caseloads - regardless of how they are structured. The educational benefit of the practice experience is not to simply do but to have the opportunity to learn effective lawyering from the process of doing. 45

Alternative models of lawyering and dispute resolution are particularly critical for law students in India to explore. Formal courts based on British colonial structures have become bogged down to the point of being essentially dysfunctional. Students need to consider what the profession's obligations are with regard to reforming whether, when and how the courts are used. As alternatives to the courts are reinstituted or created of necessity, students need to learn how to assess the extent to which they are fair and advance the common good. 46

The following sub-sections consider some experiential learning course structures. My goal is to

44 Article $39 \mathrm{~A}$ of the 42 nd Amendment to the Indian Constitution establishes the right to free legal aid. Block \& Prasad, supra note 5, at 173. The Expert Committee on Legal Aid of the Ministry of Law and Justice proposed the use of law students as an inexpensive and enthusiastic resource for providing meaningful legal aid to India's vast population. Id at 174.

45 Professor Leah Wortham put it this way, "[A] clinic within a law school should not let the education objectives of the clinic be swamped by many clients who need service. If all clinic faculty and student time is absorbed by responding to clients, there will be not time and energy to think about what the clinic is trying to teach students and how to teach that well. Likewise, it will be difficult to find time to reflect critically on why the law and legal system and society generally may not serve poor people well, to consider alternatives to the current system, and to consider alternative models of lawyering." Leah Wortham, Aiding Clinical Education Abroad: What Can Be Gained and the Learning Curve on How To Do So Effectively, 12 Clinical L. Rev. 615, 661-62 (2006) (discussing lessons learned from developing clinical legal education programs outside of the United States).

46 For example, lok adalats have been reinstituted as a means of providing access to the courts for the poor, but concerns with this informal approach to justice are not unlike the objections raised with regard to mediation in the United States. For a critique on the lok adalats and the problems to providing access to justice, see Marc Galanter \& Jayanth K. Krishnan, "Bread for the Poor": Access to Justice and the Rights of the Needy in India, 55 Hastings L.J. 789 (2004). 
provoke thought about walking the path towards structuring effective clinical programs and to consider their relationship to the rest of the law university curricula. The courses discussed are intended as a base from which to create and innovate. The skills courses should not be considered as alternatives to the clinical experiences but as part of the integrated approach throughout the curriculum to preparing students to address the issues that the clinic courses will pursue.

\section{A. Externships}

Externships offer students discreet periods of time to devote to lawyering experiences in practice settings outside of the law school. As offered in law schools in the United States, they can provide excellent opportunities for students to apply the theory they have learned in substantive law classes to the challenges of professional practice. While the classroom can endeavor to integrate the two, the practice setting offers a significant, arguably essential dimension.

The placements that I observed at NALSAR Law University reflect the experiential objectives of externships. They occurred in each of the third, fourth, and fifth years of schooling. The students spend two months, November and December, at each placement. During that same period, the university is closed for vacation. As noted above, the students find their own placements for each practice inter-session. There is no contact with the placements by the school. Furthermore, no classroom component either prepares the students for what to expect of the placement or to reflect on their experience. ${ }^{47}$ This is what distinguishes these experiences from most externship courses in the United States. Externship courses are expected to have either a classroom component or other student/teacher interaction that provides an opportunity to reflect on the placement experience. ${ }^{48}$ Often, there is direct contact between the faculty member and the placement supervisor. At a minimum, the school communicates expectations regarding the placement experience. ${ }^{49} \mathrm{~A}$ model externship program would take advantage of the generous commitment of

47 See supra note 30.

48 A useful text for teaching an externship clinic is J.P. Ogilvy et al., Learning from Practice: A Professional Development Text for Legal Externs (West 1998), and a Teacher's Manual for the text is also available. The book emphasizes the importance of helping students to assess, optimize and build upon the placement experience.

49 ABA Standards, supra note 28, Standard $305-$ Study Outside the Classroom, sets the minimum standards for externship courses at accredited law schools in the United States:

(a) A law school may grant credit toward the J.D. degree for courses or a program that permits or requires student participation in studies or activities away from or outside the law school or in a format that does not involve attendance at regularly scheduled class sessions.

(b) Credit granted shall be commensurate with the time and effort required and the anticipated quality of the educational experience of the student.

(c) Each student's academic achievement shall be evaluated by a faculty member. For purposes of
Standard 305 and its Interpretations, the term "faculty member" means a member of the fulltime or part-time faculty. When appropriate a school may use faculty members from other law schools to supervise or assist in the supervision or review of a field placement program.

(d) The studies or activities shall be approved in advance and periodically reviewed following the school's established procedures for approval of the curriculum.

(e) A field placement program shall include:

(1) a clear statement of the goals and methods, and a demonstrated relationship between those goals and methods to the program in operation;

(2) adequate instructional resources, including faculty teaching in and supervising the program who devote the requisite time and attention to satisfy program goals and are sufficiently available to students;

(3) a clearly articulated method of evaluating each student's academic performance involving both a faculty member and the field placement supervisor; 
time for experiential learning already available in the law university structure and apply requirements for supervision and placement that would help to assure that students are gaining useful exposure and insight. Basic structural considerations might include the following:

1. Students, in coordination with a supervising faculty member, find their own placements. This would engage students in evaluating placement opportunities while having faculty input with regard to learning opportunities. Depending on the need for services and the educational goals, a specific placement or group of placements may be preferable.

2. A faculty member is assigned to the externship program. This assignment would be the most, if not all, of that faculty member's teaching load. I will refer to this position as "faculty supervisor" below.

3. Any placement found by a student is reviewed by the faculty supervisor. The review would involve determining whether the placement is appropriate under the following criteria:

a. The placement is primarily involved in the practice of law or law-related activities. That the placement is in the legal department or office of a larger enterprise, such as a nongovernmental organization or business that is not primarily involved in the practice of law, is acceptable.

b. The student's activities primarily involve substantive work directly related to the practice of law. This can include a wide range of work, from litigation to mediation to clerking for judges to transactional practice to legislative and social service advocacy. It could even include journalism, so long as the placement develops skills and insights relevant to professional development as a lawyer.

c. The placement supervisor is a lawyer. While there are many things to learn from nonlawyers, the goal should be development of professional skills and perspective.

d. The placement supervisor is willing to provide to the faculty supervisor a general outline of the work the student will do during the placement. The faculty supervisor would discuss this outline with the placement supervisor as well as educational goals for the student. A written agreement about the placement should follow that discussion.

e. There is an opportunity to understand and address issues affecting the socially or economically disadvantaged, or to address environmental and other important social justice issues. This aspect of the externship experience should be explored in class or meetings with the faculty supervisor.

(4) a method for selecting, training, evaluating, and communicating with field placement supervisors;

(5) periodic on-site visits or their equivalent by a faculty member if the field placement program awards four or more academic credits (or equivalent) for field work in any academic term or if on-site visits or their equivalent are otherwise necessary and appropriate;

(6) a requirement that students have successfully completed one academic year of study prior to participation in the field adjacent program;

(7) opportunities for student reflection on their field placement experience, through a seminar, regularly scheduled tutorials, or other means of guided reflection. Where a student can earn four or more academic credits (or equivalent) in the program for fieldwork, the seminar, tutorial, or other means of guided reflection must be provided contemporaneously. 
f. Student housing accommodation is determined to be satisfactory and safety is considered. This is worth noting in program development since the school has some responsibility for the circumstances that attend students pursuing this aspect of their education, particularly since the students are young and often unaccustomed to being on their own.

4. Each student is required to provide to the faculty supervisor an outline of goals for the placement experience.

5. Prior to leaving for their externships, the faculty supervisor meets with each year of externship students in several classes to discuss what the placement should mean in their professional education. Specifically, the discussions would help students establish goals for their experience, develop tools for reflecting on their experiences, and learn how to seek and receive useful feedback during their externships. 50 The discussion should change for each year, with the goal being to develop the expectations and level of reflection for each progressive year's placement.

6. Prior to embarking on the externship placements, the faculty supervisor also meets with students, individually or in small groups, to discuss the placement supervisor's outline of work in relation to the students' goals for their placements. Students should have a good understanding of goals and expectations prior to leaving for their externship. Strategies for dealing with supervisors who do not provide the substantive experience contemplated are also important to cover in these meetings.

7. Keeping journals during their placements would encourage students to analyze their placement experiences. These journals can be collected by the faculty supervisor and form part of the externship assessment, or they can simply be used for debriefing discussions in class upon the students' return. Journals expose students to the discipline of thinking deeply about their actions and the actions of others around them. Particularly in the externships where rounds and other clinical teaching tools may not be part of the practice experience, they encourage students to take responsibility for analyzing their experiences and learning from them. ${ }^{51}$

8. At the end of the externship experiences, small group sessions are held with students to discuss the externship experience. Students should be prepared to discuss what they did, how it responded to the goals they had set, how their experiences provided opportunities to apply the substantive law they had learned during the preceding semester, poverty issues and potential solutions, and any other relevant reflections.

9. The school keeps a roster of placements that did not work out so that students may avoid them in the future. 52

50 See BEST PRACTICES supra note 32 at 176-177 (recommending that students learn how to gain the most educational value from feedback provided through experiential courses by being open and attentive to critique; seeking clarification; focusing on specifics in order to improve future performance; seeking a variety of input; synthesizing the feedback provided; and reviewing the input provided).
51 See, J.P. Ogilvy, The Use of Journals in Legal Education: A Tool for Reflection, 3 Clinical L. Rev. 55 (1996)(discussing the benefits of journals as a tool for encouraging students to critically assess their experiences).

52 Columbus School of Law does this for its externship program. Students are asked to provide feedback about placements and placement supervisors. This feedback, both good and bad, is 
The goal, then, is to provide more structure to the placement opportunities and faculty-guided reflection to the placement experiences, while preserving some of the range of placements and the student initiative that was in evidence at NALSAR.

\section{B. Skills Courses.}

In July 1992, an assessment of what competencies lawyers need to be effective professionals was done at the behest of the American Bar Association's Council of the Section of Legal Education and Admissions to the Bar. The task force that conducted the study was chaired by prominent lawyer and past ABA president Robert MacCrate, and the report that was issued has commonly been referred to as the MacCrate Report. ${ }^{33}$ Central to the report was an analysis of the skills and values essential for competent representation. The skills listed by MacCrate were: problem solving; legal analysis and reasoning; legal research; factual investigation; communication; counseling; negotiation; litigation and alternative dispute resolution procedures; organization and management of legal work; and recognizing and resolving ethical dilemmas. The values identified were: provision of competent representation; striving to promote justice, fairness and morality; striving to improve the profession; and professional self-development. ${ }^{4}$

These skills and values provide a useful outline of a range of competencies that can be used as a reference point for framing a law school curriculum. In fact, this is exactly what the MacCrate Report urged. The MacCrate Report had a modest impact on legal education in the United States. It was criticized as being overly broad to the point of being irrelevant to values such as social and economic justice and to the changing roles of the lawyer in a lawyer and client relationship. 55 The report's limitations as well as the differences between India and the United States make uncritical reference to the MacCrate analysis risky for several reasons. India is still extracting itself from the ongoing impact of a colonial legal system. It is also combating pervasive poverty exacerbated by religious and caste prejudices. Economic development, energy, environmental and infrastructure challenges call for attention in different ways in each country. Yet, these issues are primarily a matter of degree. Poverty, prejudice, lack of education, lack of legal representation, and cluttered court dockets are common to both countries. This suggests that India may place different emphases in applying the skills and values enumerated by the MacCrate Report, as well as consider the extent to which additional or alternative skills and values are more meaningful and explicit. ${ }^{56}$

kept in binders. My suggestion is that the externship supervisor take an active role in assessing the placement experience through contact with the supervisor and feedback from the student. If the experience has not been a good one for reasons primarily associated with the setting and supervision provided, then future students should be instructed to avoid that placement.

53 MacCrate Report, supra note 33.

54 Id. at 138-221. See also Menon, supra note 3, at 41 91; ABA Standards, supra note 28, at Standard 302

(b) A law school shall offer substantial opportunities for:

(1) live-client or other real-life practice experiences, appropriately supervised and designed to encourage reflection by students on their experiences and on the values and responsibilities of the legal profession, and the development of one's ability to assess his or her performance and level of competence;

(2) student participation in pro bono activities; and

(3) small group work through seminars, directed research, small classes, or collaborative work.

55 See Russell G. Pearce, MacCrate's Missed Opportunity: The MacCrate Report's Failure to Advance Professional Values, 23 Pace L. Rev. 575 (2003) (criticizing the MacCrate Report as failing to emphasize the teaching of values as high a priority as teaching lawyering skills).

56 See Bloch \& Prasad, supra note 5, at Part III (discussing the need for India to adapt the MacCrate Report to its own needs and proposing a modified set of skills and values.). 
Identifying the skills and values that are components of legal education is the first step to determining how they will be taught. Once identified, they need to be integrated into the teaching of traditional subjects in the classroom setting so that understanding of substantive law is connected to its professional application. ${ }^{57}$ A torts or personal injury course will teach legal analysis and reasoning, but it must also engage students in problem solving and critique of issues such as caste, class and gender and address issues of justice, fairness, and morality in considering how tort law applies and should apply in serving the community. This aspect of the course need not be in conflict with the need to cover a significant body of substantive law. ${ }^{58}$ Balance is essential. 59 Students should be aware in each of their courses of the interrelationship of legal precepts, contextual realities and legal practice so that they can gain a sense of professional connection and lay a foundation for competence.

While teaching professional skills may be reinforced in teaching substantive courses, courses dedicated to developing skills are also necessary. For example,

1. Legal research and writing are fundamental and should be introduced through a structured course or series of courses taught by expert law faculty. Certainly, the move in this direction has been a painful one in the United States. ${ }^{60}$ However, its importance is reflected in the accreditation standards for law schools in the United States: schools must require two legal writing courses of all students prior to graduation. Apart from professional responsibility, this is the only specific course requirement in the accreditation standards. ${ }^{61}$ The ability to gather, synthesize and use information is essential for lawyers to know regardless of the context in which they will apply those skills. Research and writing may result in pleadings, briefs or argument in court, but may also be used to inform community education projects, alternative dispute resolution approaches, public advocacy, and problem solving in general.

57 EDUCATING LAWYERS, supra note 38 at 190191 (noting that the MacCrate Report considered the skills and values it advocated as additions to the law school curriculum instead of more appropriately viewing them as teaching objectives throughout the curriculum).

58 See, e.g., Margaret Martin Barry, Jon C. Dubin \& Peter A. Joy, Clinical Education for This Millennium: The Third Wave, 7 Clinical L. Rev. 1, 41-44 (2000) (discussing the inclusion of a live-client clinic experience in first year courses in law schools in the United States).

59 Law teachers often feel driven to cover substantive legal information without faith in exchanging some of that coverage to challenge students to understand and engage in constructive critique of the circumstances and practices that bring the issues into being. See Sexton supra note 32.

60 See Joan S. Howland \& Nancy J. Lewis, The Effectiveness of Law School Legal Research Training Programs, 40 J. Legal Educ. 381, 390 (1990) (attributing students' negative attitudes towards legal research to the low value law schools place on research skills in the curriculum; they "are often taught by nontenure-track faculty, are ungraded, and frequently are not particularly rigorous."). See also James B. Levy, The Cobbler Wears No Shoes: A Lesson for Research Instruction 51 J. Legal Educ. 39 at n. 15 and 2 (2001) (making the same observation). Consistent with these observations, legal writing instructors receive the least protection of all teaching faculty under the Standards; the extent of the security of position for these teachers falls far short of tenure - schools need offer no more than short-term contracts to their legal writing faculty. ABA Standards, supra note 28, at Standard 405(d) and Interpretation 405-9.

61 ABA Standards, supra note 28, at Standard 302 states:

(a) A law school shall require that each student receive substantial instruction in:

(1) the substantive law generally regarded as necessary to effective and responsible participation in the legal profession;

(2) legal analysis and reasoning, legal research, problem solving, and oral communication;

(3) writing in a legal context, including at least one rigorous writing experience in the first year and at least one additional rigorous writing experience after the first year.... 
2. Interviewing and Counseling, Negotiation, Trial Practice, and Alternative Dispute Resolution are four additional skills courses that should be considered. They are not exclusive remedies, and some may be irrelevant to areas of needed service in India. However, they are tools lawyers use and law graduates should have a basic understanding of these competencies in order to effectively assess their utility.

This is particularly true of Alternative Dispute Resolution. The growing interest in ADR in the United States is a direct result of frustration with cluttered court dockets, resulting delays and poor service. Congestion in Indian courts is far greater. 62 As a result, a variety of alternative approaches have developed, but the integrity of these alternatives requires greater analysis. ${ }^{63}$ It is important for students to learn about, critique, and, where necessary, explore alternatives to various methods used.

Effective teaching of these skills courses requires participation in a series of simulations that challenge students to integrate assigned readings as they develop basic competencies. Thus, it is hard to consider teaching these courses effectively in classes having more than sixteen to twenty students. Student opportunities to participate in sufficiently supervised simulations would be compromised in larger classes. This means dedicating several sections within a given year of students to covering each set of skills, and possibly linking the skills sections to a larger substantive course for greater impact. ${ }^{64}$

3. Moot court competitions are already quite popular at the law universities. These simulated appellate arguments help develop research and writing and persuasive oral argument skills. 65 However, moot court participation should be in addition to legal research and writing courses, and the important oral skills learned cannot be viewed as unrelated to or supplanting the skills needed to creatively address social and economic justice problems.

62 The logjam in Indian courts is renowned. See Krishnan, supra 18 at 497; Jaynath K. Krishnan, Social Policy Advocacy and the Role of the Courts in India, 21 Am. Asian Rev. 93 (2003); and Galanter \& Krishnan, supra note 46.

63 "Parliament passed the Legal Services Authority Act, 1987, which aims at both providing free legal aid and organizing lok adalats (people's courts) to secure quick justice at low cost." Bloch \& Prasad, supra note 5 , at 173 . "Lok adalat settlement is no longer purely a voluntary concept. ... Cases can be referred by consent of both parties to the disputes, where the Court is satisfied that the matter is appropriate to be taken cognizance of by the lok adalat ... Settlements shall be guided by the principles of justice, equity, fair play and other legal principles; if agreement is reached by the consent of the parties and passed on by the conciliators, the award is final and the matter need not be referred back to the concerned court for consent decree; if no compromise is reached through conciliation, the matter shall be returned to the concerned court for disposal in accordance with law . . . . Id at 212, n.135. . See also, Galanter \& Krishnan supra at 804805.

64 See Don Peters, Mapping, Modeling, and Critiquing: Facilitating Learning Negotiation, Mediation, Interviewing, and Counseling, 48 Fla. L. Rev. 875 (1996) (recommending that faculty members who teach large classes can collaborate with lawyers who can map, model and critique smaller simulation sections of the larger course).

65 This first of the Practical Paper requirements required under Indian law seems to be the most seriously pursued. See Bloch \& Prasad, supra note 5. 


\section{Clinical Programs.}

An in-house clinic (one run by the university for purposes of teaching its students and providing service to the community) ${ }^{66}$ or a hybrid clinic (one that collaborates with an existing legal services office to provide representation $)^{67}$ is a carefully constructed integration of client service and contextual learning. Students must reference their substantive law and legal skills education and expand on both in the course of providing effective service.

In the United States, in-house and hybrid clinics serve clients who are unable to pay for legal services or who are unable to find representation. Clinics have traditionally sought such clients in order to emphasize for students their professional obligation to assure access to justice. Furthermore, student practice rules generally limit representation to the same body of clients. 68 The purpose of limiting service to indigent clients avoids competition with the private bar and inculcates the same sense of professional obligation. ${ }^{69}$

A clinical course run by the university and taught by its faculty, allows students to participate in legal service that is designed to maximize their learning. When in a student's law school career to provide such clinical experiences has been the subject of experimentation and debate. Some have argued that it should start immediately, to avoid the damage otherwise done in first year law

66 The definition given back in 1992 by a special committee of the Association of American Law Schools has not been improved upon. It is quoted below both for what it has to say about clinical teaching methods and in-house clinics.

Clinical education is first and foremost a method of teaching. Among the principal aspects of that method are these features: students are confronted with problem situations of the sort that lawyers confront in practice; the students deal with the problem in role; the students are required to interact with others in attempts to identify and solve the problem; and, perhaps most critically, the student performance is subjected to intensive critical review.

If these characteristics define clinical teaching, then the live-client clinic adds to the definition the requirement that at least some of the interaction in role be in real situations rather than in make-believe ones. That is, the interaction with others in role occurs with real clients and participants in the legal system rather than with other students and actors. The nature of the real issues and cases in the liveclient clinic provides both concreteness and complexity to the student's learning experience.

The in-house clinic further supplements the definition of clinical education by adding the requirement that the supervision and review of the student's actual case (or matter) . . . be undertaken by clinical teachers rather than by practitioners outside the law school. Although the clinical movement began with practitioners used as supervisors, many clinical teachers came to believe that student supervision by practitioners was problematic for a methodology in which teaching was not incidental to the enterprise but rather its primary function. While a practitioner might be a superb lawyer, she would be unlikely to have the training, experience, or time to devote to the teaching role that a full-time clinical teacher would.

Robert Dinerstein, Report of the Committee on the Future of the In-House Clinic, 42 J. Legal Educ. 508, 511 (1992).

67 See Barry et al., supra note 58, at 28; Margaret A. (Peggy) Tonon, Beauty and the Beast - Hybrid Prosecution Externships in a Non-Urban Setting, 74 Miss. L.J. 1043 (2005).

68 Student practice rules in the United States allow students to appear in court on behalf of their clients under the supervision of faculty members and, in certain instances, other attorneys. See Jennifer A. Gundlach, This is a Courtroom, not a Classroom": So What is the Role of the Clinical Supervisor? 13 Clinical L. Rev. 279, 287-288 (2006) (discussing the impact of the student practice rule on the development of clinical programs).

69 See Robert R. Kuehn, Denying Access to Legal Representation: The Attack on the Tulane Environmental Law Clinic, 4 Wash. U. J.L. \& Pol'y 33 (2000). For discussions of the student practice rules in the United States, see Student Practice as a Method of Legal Education and a Means of Providing Legal Assistance to Indigents: An Empirical Study, 15 Wm. \& Mary L. Rev. 353(1973-1974); Sara B. Lewis, Rite of Professional Passage: A Case for the Liberalization of Student Practice Rules, 82 Marq. L. Rev. 205 (1998);Peter A. Joy, Ethics of Law School Clinic Students as Student-Lawyers, 45 S. Tex. L. Rev. 815 (2004) (discussing ethical student practice rules in the United States and related ethical issues). 
courses that are too removed from the profession. ${ }^{70}$ If the law universities are committed to building a strong clinical and skills curriculum, it would seem that the in-house and hybrid clinical experiences may have the greatest impact as part of the students' initial law school experience, with levels of responsibility escalating in each year. Thus, students would begin as part of the clinic enterprise, but with very limited tasks, with their responsibilities progressing such that by their last year they are performing as many of the lawyering tasks as possible. Alternatively, the clinic experience could be approached as a capstone to the progressive range of skills developed as part of the curriculum. If the curriculum requires externship experiences and uses experiential learning methods such as simulation, role-plays and so on early on, then by the last year students would prepared to step into the role of advocate or mediator in the complicated context of real life situations. This is particularly true for students who enter law school from high school, as they do in India. A capstone clinic experience would come after they have had the chance to mature, both in terms of life experience and understanding legal potential. The approaches suggested by need for services, teaching goals, and experimentation should make consideration of when and how to engage students a fluid and innovative process. ${ }^{71}$

Issues of when, what and how to organize the clinic offering require careful assessment of learning objectives and community needs. ${ }^{72}$ The 1977 Report on National Juridicare observed that "there are no two opinions about it that there is need to reform the system of legal education in the direction of making it poverty-oriented, multi-disciplinary and related to actual social conditions." 73 The report described its goal as building "a cadre of poverty lawyers competent to run a nation-wide legal services programme."74 A cadre of public interest lawyers is certainly an attractive goal, and, making clinic available to such a discreet group may be the best way to initiate clinical programming. ${ }^{75}$ However, the broader goal of clinic and an integrated curriculum is to

70 See Michael A. Millemann \& Steven D. Schwinn, Teaching Legal Research and Writing with Actual Legal Work: Extending Clinical Education into the First Year, 12 Clinical L. Rev. 441 (2006). See also Barry et al., supra note 58 .

71 See, e.g. V. M. Salgaocar College of Law Legal Aid Society supra note 30.

72 Making clinical programs available to all students is a challenge. Attempting large scale live client offerings raises the specter of over-extended supervision and poorly conceived client services. One evening at dinner, a few months after returning from my visit at NALSAR Law University, I discussed my concerns about implementing a clinical program at NALSAR with Professor Leah Wortham and Ms. Nimushakavi Visanthi (Ms. Visanthi happened to be visiting at Washington School of Law). Professor Wortham was relating her view that it is far more realistic to contemplate setting up a small program available to a several students per semester or year, and viewing that program as the basis for developing a solid program that is responsive to the unique needs of the particular social setting. This was a liberating view since I had felt had been intently focused on the need to make the live-client clinical experience available to all students at the university, in short order. Professor Wortham developed her views in her Aiding Clinical
Education Abroad article, supra note 45.

73 Menon, supra note 3, at 21 (citing Report on National Juridicare: Equal Justice, Social Justice, Ministry of Law and Justice, Govt. of India, 1977).

74 Id.

75 From my brief conversations with the fifth year students who I taught at NALSAR, with the possible exception of two who were inclined to pursue a criminal defense career, none considered public interest work an option they would pursue. Many felt either inclined or pressured to take corporate jobs because they are viewed as lucrative. A few wanted to enter their families' practices. Still others wanted nothing to do with law, had no idea what area to practice in, or wanted to use their law degrees in another profession. A fair number also wanted to continue their studies, including many of those who envisioned doing corporate law. Not one specified poverty law as an area of interest, although there may have been a few who felt inclined that way and expressed it as dissatisfaction with the profession. The disinterest could be attributed to lack of exposure to poverty law, but it seems overkill to seek to make students poverty lawyers, as opposed to lawyers who, in addition to their legal career goals, understand how to effectively apply their expertise in service to the poor and underserved. 
expose students to poverty law issues in the hope that, while a significant number may then be inspired to pursue poverty law practice, others will pursue these issues through or in addition to their ultimate area of practice. ${ }^{76}$

Another basic consideration is whether the clinic should be a hybrid or in-house program. If the clinic is to be in-house, then the law university must assess what type and scope of legal service its clinic will provide. Relevant considerations would be: what community is to be served; what service is needed in the community; what lawyering competencies it is most important for the students to develop; what service is the university particularly interested in providing; and what area of practice the clinical faculty is best qualified to teach or most interested in pursuing. 77 There may be a great need for representation in the community surrounding the university, but the areas of legal expertise required to respond effectively may be beyond the expertise or educational priorities of the university; or the university may want to be identified as a general legal resource for that community and this choice will influence clinic development. Deciding which approach to take should involve the faculty in a discussion of the university's role in introducing students to creative lawyering approaches and fostering a climate of innovative problem solving. Thus, the decision of what type of clinic is best seen as framing the clinic entity and possibly the initial issues and approaches the program will focus on, but would be truest to desired educational and service goals if it is designed with sufficient flexibility to respond to needs identified as a result of community involvement.

The hybrid clinic may provide more breadth with regard to areas of practice and the types of expertise students can reasonably develop. A legal aid office or non-governmental organization (NGO) may handle a wide range of legal matters in ways that members of the law faculty may not have anticipated. Dividing the students among non-faculty supervisors with expertise in a range of issues and approaches allows students to develop a sense of competence while operating in a general practice setting or NGO. Depending upon the relationship with the collaborating office and clinical program goals, clinic faculty may or may not provide direct supervision. Possible models for supervisory collaboration would have the faculty member supervising some assignments that do not involve court appearances, co-supervising all assignments or closely observing the developments in activities supervised by placement attorneys while working closely with them on

76 The skills taught in clinic are intended to be transferable. Skills poverty lawyers use to address the needs of their clients are similar to those used in many legal settings. Interviewing, assessing facts, developing case theories, investigation, legal research, problem solving, client counseling, advocating in a variety of forums, and even community education are skills that lawyers use and that students should have exposure to prior to completing their professional education. This was the approach I took in raising issue of poverty, access to justice, limitations in legal responses, and disparate impact when teaching at NALSAR. Having spent my first class learning about the students and their goals and interests, I knew that it was important to discuss the hypothetical I used and issues I wanted to raise in a way that would resonate for them. I urged them to consider their responsibility to address these issues regardless of the practice they chose to pursue. All lawyers have an obligation to recognize and respond to the needs those who society overlooks or mistreats or the compelling problems that are ignored. In fact, opportunities to explore this obligation exist and should be pursued throughout the law school curriculum. See Jane H. Aiken, Provocateurs for Justice, 7 Clinical L. Rev. 287 (2001) (discussing the opportunity clinics offer to inspire law students to commit to justice and the need for clinical faculty to provoke a desire to do justice in their students).

77 Professor Wortham observes in the context of promoting the institution of law school clinics, "Given my view of the importance of involving faculty and the usual situation in which many areas of law present legal needs for poor people and under-served interests, I think it is legitimate to focus a clinic in an area of faculty enthusiasm." Wortham, supra note 45 , at 671 . 
student supervision. ${ }^{78}$ Additionally, the faculty role should involve teaching or co-teaching a classroom component of the course that covers relevant skills and substantive law and that includes rounds that provide students with the opportunity to reflect on their work.

The hybrid clinic model assumes a commitment on the part of the legal aid office or NGO to assist with educational goals of the clinic and closely collaborate with the clinic faculty. Ideally, the relationship benefits all involved in that the degree and quality of the services provided by the outside entity are enhanced by connection with the university, its faculty and students.

Another consideration with regard to whether or not to choose a hybrid or an in-house clinic is the possible need for the university to fully staff the in-house clinic office year round. Coverage for faculty members who may want to write, who will need vacation time or may become ill must be considered, especially since clinic projects may extend beyond the academic semester. Rotating faculty responsibilities might avoid this problem as well as contribute to integrating clinical and substantive law teaching. Coverage considerations are less compelling where the clinic enterprise operates in collaboration with a legal aid office in a hybrid clinic.

Clinic location is another consideration. Should the clinic be viewed as an office to which clients come or a base from which students span into the community? In either event, an office creates a space for student interaction and support. Should it also be an identifiable resource for the community? If so, should it be located on campus or in the target community? Should it be mobile or static? These will depend on a number of factors, including the type of clinic, the location of the law school, space needs and availability. Accessibility to the population served should be a primary consideration, but may well be trumped by budgetary and other considerations.

How to assign students to the planned services is another consideration. Should they be teamed? Teaming students provides an opportunity to develop a skill of increasing importance to legal, as well as other, professional practice: collaboration. Students are often trained to work independently prior to entering law school and during much of their law school careers. One of the goals for integration of clinical methods throughout the law curriculum would be to encourage collaboration in the classroom and on course assignments in order to prepare students to work effectively in professional practice. ${ }^{79}$ By extension, within the clinic such collaboration is created through teaming and by creating an environment in which students share ideas with regard to each other's work.

What kind of work to assign is a separate issue. While this issue will inevitably be driven by the kind of service to be provided, assignments should be manageable and provide some opportunity to build expertise. With regard to law clinics in the United States, some have argued that practice limited to a specific area of law allows students to understand the issues related to that type of practice more clearly and provides the opportunity to develop reasonable competence with regard to the subject matter. A contrary view holds that specialization trains students to fit their clients'

78 See Barry et al., supra note 58, at 28 (discussing approaches to hybrid clinics and the relative economic benefits of this approach).

79 See Janet Weinstein \& Linda Morton, Interdisciplinary Problem Solving Courses as a Context for Nurturing Intrinsic Values, 13 Clinical L. Rev. 839, 847 (2007); David F. Chavkin, Matchmaker, Matchmaker: Student Collaboration in Clinical Programs, 1 Clinical L. Rev. 199 (1994). 
problems into a subject matter box. 80 Such considerations may or may not be as relevant to approaches identified for addressing problems India. Still, the consideration flags the importance of assessing the types of legal assignments the students are given with an eye towards connecting the services provided to the educational goals of the clinical program. Central to any model pursued will be a commitment to optimizing student learning. The goal is to develop lawyers who will be able to effectively address community needs, and not to confuse this goal with using the students as the solution to legal service needs.

One of the tools the lawyer is expected to have is the ability to use litigation as an option for solving client problems. Since students in the United States practice under the supervision of a licensed attorney, usually their clinic professors pursuant to the student practice rules of the relevant state, students are able to take primary responsibility for the full range of representation that may be provided by a lawyer, including the traditional role of litigating before the courts. ${ }^{81}$ While, as noted above, a solid clinical experience could be fashioned around a program that does not involve the ability to enter the courts, the option to pursue such a remedy would provide the student the opportunity to experience the benefits and limitations of this aspect of legal practice.

Another consideration is language barriers to effectively serving the poor. Language barriers can pose significant challenges, even as they offer opportunities for learning professional skills. In order to serve the poor in India, language differences will need to be addressed. Many underserved clients speak only the local state language, while the students who come to the law universities often come from several Indian states. The students and faculty share Hindi and English, but these languages are often not shared by the poor. ${ }^{82}$ Thus, interpreters are necessary to assist with the complex communication needed for competent representation. Law universities may need to hire interpreters to work with their students in an in-house clinic, or as part of facilitating the interface in a hybrid clinic setting. ${ }^{83}$ Learning to work with interpreters is a useful skill for students to develop given the strong possibility that their careers will involve the use of interpreters. One option discussed at NALSAR was requiring first year law students to learn the local language. While this would send students an important message with regard to communication and cultural

80 See, e.g., Antoinette Sedillo Lopez, Learning Through Service in a Clinical Setting: The Effect of Specialization on Social Justice and Skills Training, 7 Clinical L. Rev. 307 (2001) (discussing the pros and cons of specializatin, and arguing that specialization makes it more difficult to serve the myriad needs of clients and it limits students' ability to be creative problem solvers).

81 See supra note 68.

82 Telugu is the language spoken in the portion of Andhra Pradesh in which NALSAR is located. For many poorer members of the community, Hindi and English do not supplement their native language. Students at NALSAR are both educated and diverse. They come from many parts of India, and thus many do not know Telugu, although they do know Hindi and English. In order to help underserved local residents, they will need to know Telugu or work through interpreters. There has been some thought that students in their first year at NALSAR should be required to learn Telugu, as a way of acknowledging the host community and as a way of underscoring the need to reach out to the poor. Familiarity with the local language and culture could also complement the social science goals of the first two years of the law university curriculum.

83 See Washington College of Law, American University, Ad Hoc Committee on Serving Clients Having Limited English Proficiency, Bellow Scholar Program Proposal: Developing a Collaborative Model for Delivering Legal Services to Clients with Limited English Proficiency Attached, with permission, as Appendix A (discussing the committee's considerations with regard to the use of interpreters). See also Angela McCaffrey, Don't Get Lost in Translation: Teaching Law Students to Work with Language Interpreters, 6 Clinical L. Rev. 347 (2000) (discusses teaching methodologies and language access issues - while the focus is on law in the United States, the article offers guidance for students on when an interpreter is needed). 
competency, it may not lead to the depth of communication needed for effective problem solving.

Related to the use of interpreters is this idea of developing cultural competencies. ${ }^{84}$ Religious, cultural, caste, class, economic, gender, and experiential differences all suggest an imperative to develop awareness among students of their need to be responsive to the impact of difference on their ability to serve their clients effectively. Assumptions about similarities and differences can inhibit or confuse communication despite the deepest commitment to service. 85 They can also narrow the perspective needed to engage in the creative problem solving that society demands.

There are a number of considerations with regard to faculty who teach clinical courses that have gotten in the way of successful clinical programming in the United States that India will hopefully avoid. Parity with other law faculty has been an ongoing battle in law schools in the United States. The American Bar Association, in its role as law school accrediting agency, has established that a form of parity is necessary, though it has equivocated on the issue. 86 The status of clinical faculty has direct implications for the quality of clinical programming, and for the integration of clinical methodology throughout the curriculum. Faculty teaching clinical courses should be full members of the law faculty. A status that limits input in law school governance, for example, or provides a less secure faculty position or regard, could affect program integrity and efforts to integrate clinical methodology and skills in general throughout the curriculum. ${ }^{87}$ Furthermore, a secondary status sends the message to students that clinical and skills courses are not as central to their legal education as substantive law coverage. I have no sense that this is or would be an issue in India. It appears that faculty members involved in clinical courses are not a separate category of teachers, and, in fact, teaching clinic is in addition to robust course loads. However, teaching assignments may become more tailored to the demands of clinical teaching as clinical programming develops within the law universities. With that in mind, it is important to avoid the unfortunate stratification and dissociation amongst teachers that exists in some law schools in the United States as that may inhibit the curricular integration that has been identified as a lacking in American legal education. 88

Course load is another consideration regarding faculty. As with the externship program discussed above, teaching the in-house or hybrid clinic should occupy most, if not all, of a faculty member's teaching load. In the United States, it has generally been accepted that a full teaching load has clinical faculty responsible for approximately eight students for an in-house clinic, with adjustments made based on the number and complexity of the cases assigned and the credit hours

84 See Susan Bryant, The Five Habits: Building CrossCultural Competence in Lawyers, 8 Clinical L. Rev. 33 (2001) (discussing methods for developing cultural competence).

85 In our Families and the Law Clinic, my colleague Catherine F. Klein and I use exercises based Professors Susan Bryant and Jean Koh Peters' work and on ideas about storytelling based on our exposure to the work of Jo Tyler to explore these assumptions between teachers and students. We then expand the exploration to issues of difference between students and their clients. See "Cross Cultural Lawyering" (role-play on this approach as presented at City University of New York (CUNY)
School of Law by Professors Barry and Klein, on file with the author). See also, Bryant, supra.

86 ABA Standards, supra note 28, at Section 405(c) seek to establish a floor for the treatment of clinical faculty, but fail to require parity by only requiring "reasonably similar tenure" as to other full-time faculty.

87 See, e.g., Wortham, supra note 45; Keith A. Findley, Rediscovering the Lawyer School: Curriculum Reform in Wisconsin, 24 Wis. Int'l L.J. 295, 308-9 (2006).

88 See generally, EDUCATING LAWYERS, supra note 38, and BEST PRACTICES, supra note 32. 
granted for the course. ${ }^{89}$ More students can be supervised in a hybrid program, but numbers depend on the kinds of cases and level involvement by the faculty supervisor.

Part of the resistance to clinical programming in the United States has been the expense. The low student/faculty ratios considered appropriate for high quality clinical programs have led schools in the United States to be creative in hiring fellows or practitioners-in-residence to help teach. ${ }^{90}$ As argued with regard to law schools in the United States, finding the resources for quality clinical legal education is a matter of priorities. ${ }^{91}$ Committing to clinical legal education will require identifying it as a priority in allocating the limited resources available.

Licensure for law faculty is an issue that might need to be addressed for purposes of establishing an in-house clinic, and, depending upon the level of involvement in any trial work anticipated for the hybrid, for that model as well. Apparently, the prohibition on licensure of law faculty is based on concerns about compromising the quality of legal education if faculty members are allowed to practice. ${ }^{92}$ However, practice prior to joining and to a modest extent while on a law faculty would provide an important connection to the traditional center of the profession being taught. 93 Furthermore, the absolute prohibition seems excessive in that concerns about employment priorities should be able to be handled as a matter of law school administration, not licensure. The limitation means that law faculty are institutionally isolated from part of legal practice and thus from part of the profession they seek to teach. It also contradicts the spirit of if not the opportunity for the clinical experience espoused as part of the Indian legal education reform movement. Nonetheless, programmatic goals for clinical legal education can be met without entering a courtroom. This is especially true where, as in many parts of India, dispute resolution

89 Report of the Committee on the Future of the In-House Clinic, supra note 66 at 552 (reporting that the average student teacher ratio was 1:8, with $84 \%$ of schools reporting ratios of $1: 10$ or better). "The ideal ratio varies with the goals of the clinic, the nonsupervision demands placed on the clinical teacher, the number of credit hours that each student earns, and the types of cases that the clinic handles." Id. See also BEST PRACTICES, supra note 32, at 179 (discussing "Experiential Courses" and observing that, "[t]he demands of experiential teaching are different from non-experiential teaching, and schools should take care to ensure that the student-faculty ratios, caseloads in in-house clinics, and the overall obligations of experiential teachers are conducive to achieving the educational programmatic goals of their courses. One must balance the need to give students meaningful experiences against the risk of overloading students or teachers and interfering with their abilities to achieve the educational goals of their courses.").

90 For example, Georgetown University Law Center hires fellows who, in addition to a modest stipend are able to work towards a specialty in clinical education. American University's Washington School of Law hires practitioners-in-residence who are not on a faculty track and who are expected to leave after two years of teaching.
91 See Barry et al., supra note 58, at 8-11.

92 See supra note 28.

93 In describing the gap between expectations and reality with regard to legal education and practice, the MacCrate Report observed that the practicing bar complains that graduates "can't draft a contract, they can't write, they've never seen a summons, the professors have never been inside a court-room," to which the law schools respond "[w]e teach them how to think, we're not trade schools, we're centers of scholarship and learning, practice is best taught by practitioners." The report argues that the "the skills and values of the competent lawyer are developed along a continuum that starts before law school, reaches its most formative and intensive stage during the law school experience, and continues throughout a lawyer's professional career." MacCrate supra note 33, at 3-4. "[T] here is no 'gap'. There is only an arduous road of professional development along which all prospective lawyers should travel." Id. at 8 . Regardless of the degree to which it is considered wise for law faculty to engage in practice, to not allow practice by those who teach seems inconsistent with professional education. Certainly that is underscored when the clinical teaching methods are considered. 
in a range of venues that offer alternatives to the judicial system is the likely extent of adjudicative services that are available. ${ }^{94}$

These frames or baselines for proceeding with clinical programs at the law universities respond to the relative lack of initiative observed compared to the express support for clinical legal education in India. The pace of clinical program development is distressing because educating lawyers has the potential to have an impact on every strata of Indian society, raising awareness and constructive responses to the considerable social imbalances that threaten the country's development. The need for legal literacy and access to meaningful dispute resolution alone is sufficiently acute that the country is well-suited to establish the standard for what legal education can do to provide models for justice system.

\section{Making a Road by Walking}

The law universities have changed the landscape of legal education in India. Their size, their relative independence and their resources set them apart. They have the potential, and the mandate, to provide their students with significant experiential learning. They can benefit from the critique of law schools in the United States, particularly the consistent failure to achieve the potential of clinic and skills training, by integrating both into the law school curriculum.

The Bar Council and its commissions have spent considerable energy identifying changes in the approach to legal education. A focus of the recommendations has been the need to establish clinical programming as an important aspect of improving professional preparation and developing a commitment to social justice. With that in mind, the issues raised in this article identify some strategies for moving forward, and will hopefully provide support for the training that many law teachers across India have recently been receiving through the efforts of the South Asian Forum of Clinical Law Teachers and the Menon Institute of Legal Advocacy Training. ${ }^{95}$

Law universities have both an obligation and a unique opportunity to prepare a generation of lawyers to approach the law with a commitment to justice and the skills to move effectively towards achieving it. Their establishment created a way to focus attention on functioning models of legal education reform. The challenge now is to teach in ways that expose students to the standards of service and excellence contemplated. A major aspect of achieving this will be to gradually implement a range of carefully planned clinical programs and connect them effectively to the rest of the curriculum, pausing regularly to evaluate the extent to which a bend in the road is indicated. We all stand to benefit from what progress is made.

94 Galanter and Krishnan supra note 46 at 789.

95 See supra note 16 discussing the trainings. 